\title{
Ekonomia społeczna a koncepcje polityki społecznej państwa. Model polski
}

\section{Maria Płonka*}

\begin{abstract}
Streszczenie: Miejsce ekonomii społecznej sytuuje sie w trójkącie: państwo - rynek - społeczeństwo obywatelskie. Celem artykułu jest okrélenie miejsca ekonomii społecznej na tle polityki społecznej państwa. W artykule, w oparciu o analizę historyczną, dokonano przeglądu najważniejszych koncepcji polityki społecznej państwa (od liberalnych po socjalne) oraz określono znaczenie sektora ekonomii społecznej w rozwiązywaniu problemów społecznych we współczesnych realiach w Polsce. W konkluzji stwierdzono, że ekonomia społeczna jest komplementarna wobec polityki społecznej państwa, funkcjonuje w warunkach alokacji rynkowej lub redystrybucyjnej, wykazuje tendencje od biernego do aktywnego wsparcia.
\end{abstract}

Słowa kluczowe: ekonomia społeczna, polityka społeczna państwa, zabezpieczenie społeczne, społeczna odpowiedzialność biznesu.

\section{Wprowadzenie}

Miejsce ekonomii społecznej sytuuje się w trójkącie: państwo - rynek - społeczeństwo obywatelskie [Hausner, 2008, s. 12-13], przy czym ekonomia społeczna jest komplementarna w relacji do rynku i państwa, które opierają się na odmiennych typach alokacji i powiązań. W tym kontekście ekonomia społeczna wpisuje się w nurt polityki społecznej państwa oraz koncepcji społeczno-ekonomicznych i lokuje w koncepcji polityki społeczno-ekonomicznej między socjalizacją polityki ekonomicznej a ekonomizacją polityki społecznej państwa na gruncie alokacji nierynkowej i/lub rynkowej. Te dwie osie tworzą układ współrzędnych, wyznaczający pole działalności różnych form podmiotów ekonomii społecznej. Trzecią osią tego układu współrzędnych jest "target", czyli docelowy beneficjent, lokujący się na osi od globalnego społeczeństwa obywatelskiego, po lokalnie, branżowo lub niszowo wyselekcjonowane grupy społeczne.
Celem artykułu jest subiektywne usystematyzowanie podejść w kwestii polityki społecznej państwa na gruncie historii myśli ekonomicznej i działalności społecznej oraz określenie w tym kontekście miejsca ekonomii społecznej w Polsce.

W szczególności poszukiwano miejsca ekonomii społecznej na gruncie analizy koncepcji i teorii, poddając analizie historycznej następujące pola badawcze:

- alokację rynkową i alokację redystrybucyjną dóbr,

- partykularne a systemowe rozwiązania problemów społecznych,

- zakres polityki społecznej państwa a ekonomia społeczna.

Na tle tych rozważań podjęto próbę usytuowania polskiego modelu ekonomii społecznej i określono jego ewolucję.

\footnotetext{
* Maria Płonka

Katedra Zarządzania Ryzykiem i Ubezpieczeń Uniwersytet Ekonomiczny w Krakowie ul. Rakowicka 27, 31-510 Kraków e-mail: plonkam@uek.krakow.pl
} 


\section{Rynkowy kontekst ekonomii społecznej}

Zjawiskom gospodarczym zawsze towarzyszyły pozytywne lub negatywne efekty społeczne, mające również wymiar polityczny. W gospodarce rynkowej rynek i podstawowy jego mechanizm, jakim jest konkurencja, jest podstawowym regulatorem alokacji zasobów i imperatywem działalności przedsiębiorstw, organizacji i jednostek. Mechanizm rynkowy funkcjonuje dobrze, gdy spełnione są warunki, umożliwiające jego stronom (oferentom i nabywcom) ukierunkowanie zachowań zgodnie $z$ sygnałami rynku i własnymi korzyściami.

Konkurencja jest motorem rozwoju, postępu i wzrostu efektywności, lecz w warunkach alokacji rynkowej i rywalizacji, pewna część społeczeństwa jest wykluczona, co wywołuje nierówności społeczne i poważne koszty społeczne, nie uwzględniane w strategiach uczestników rynku, lecz odczuwalne $w$ skali makro- i mikroekonomicznej. Teoretyczną ilustracją nierównej dystrybucji jest tzw. krzywa Lorenza, znana też jako efekt Pareto'. Vilfredo Pareto, analizując dystrybucję dochodów we Włoszech zaobserwował w 1887 r., iż $80 \%$ bogactwa całego kraju było własnością $20 \%$ ludności. Prawidłowość tą, znaną również jako zasadę 20/80 sformułował amerykański teoretyk zarządzania Joseph Juran w 1951 r. w pracy Quality Control Handbook [Juran, Gryna, 1988], w której zasada "nielicznych kluczowych i licznych błahych problemów" odzwierciedlała m.in. nierówną dystrybucję większości zasobów.

Według A. Hirschmana [1995], polityka i rynek to dwie główne dziedziny rządzące decyzjami podmiotów w gospodarce rynkowej, które jednak funkcjonują w całkiem różnych uwarunkowaniach i oczekują całkiem odmiennych reakcji ze strony oferentów i na-

Krzywa Lorenza jak i efekt Pareto ilustrują nieproporcjonalny rozkład dochodów ludności, patrz m.in.: [Samuelson, Nordhaus, 1989, s. 647 i dalej]. bywców. Hirschman używa terminu "wyjście" dla określenia rynkowych reakcji i zachowań niezadowolonych nabywców. Decyzje polityczne mogą być nie tylko przedmiotem wyboru (głosowania), lecz także powodem różnego rodzaju protestów, które autor nazywa "głosem", ponieważ wymuszają one zwrócenie uwagi na nieodpowiednią alokację dóbr społecznych. Kontynuując tok rozumowania Hirschmana, rynek i jego mechanizm rozwiązuje większość problemów związanych $z$ alokacją dóbr, lecz w odniesieniu do tej części społeczeństwa, która „wyszła” z rynku konieczne jest zastosowanie alokacji nierynkowej, rozumianej jako "głos".

Przyczyną marginalizacji grup i jednostek mogą być uwarunkowania przejściowe (np. bezrobocie), losowe (np. pożar), osobowościowe (np. brak zaradności), lub mogą wynikać z czynników biologicznych (np. niepełnosprawność). Pomoc grupom wykluczonym przez rynek leży w interesie całego społeczeństwa.

Powstające dysproporcje w poziomie zamożności i konsumpcji, rozwinięte państwa łagodzą przez politykę społeczną, opartą na alokacji redystrybucyjnej, oraz wspieranie rozwoju pozarządowego sektora ekonomii społecznej. Zbyt silna ingerencja alokacji redystrybucyjnej (np. pomoc społeczna) może potencjalnie doprowadzić do dysfunkcjonalności rynku i zakłócić działanie mechanizmów rynkowych, które są bardziej efektywne i motywujące.

\section{Rys historyczny przedsięwzięć społecznych}

Przedsięwzięcia społeczne mają genezę tak długą, jak problemy społeczne, które rozwiązują, czyli od zarania ludzkości. Idee i praktyka samopomocy, wsparcia funkcjonowały zawsze w ramach wspólnot plemiennych, rodowych, bractw cechowych, jednakże długo nie miały one cech sformalizowanych i systemowych. Do początków XVIII w. dominujący- 
mi formami samopomocowymi były: jałmużna, fundacje, przekazywane często jako źródło dochodów na rzecz klasztorów, cechów, szpitali, jako testamentowe wyrównanie krzywd i sposób na zapewnienie sobie zbawienia (jedną z pierwszych sformalizowanych organizacji była np. fundacja klasztoru jasnogórskiego, utworzona w II połowie XIV w.) [Leś, 2000, s. 20 i dalej]. Swoiste ubezpieczenia wzajemne tworzone były przez członków zawodów szczególnie niebezpiecznych, narażających pracowników na nieszczęśliwe wypadki a rodziny na biedę. Przykładem mogą być korporacje brackie (np. korporacje robotników żupnych z Kopalni Soli w Wieliczce organizowano już za Kazimierza Wielkiego, a Seweryn Boner zorganizował tam w XVI w. Fundusz Braterski Kopaczy, świadczący zapomogi w razie wypadku, choroby, działający do II wojny światowej). Na podobnych zasadach działały maszoperie kaszubskie (rybacy), gwarectwa górnicze, cechy rzemieślnicze, gildie kupieckie, bractwa czeladnicze, komuny miejskie, wspólnoty gminne, stowarzyszenia ogniowe, związki groblowe oparte na wzajemności. Jedną z najstarszych, istniejących do dziś, organizacji samorządu zawodowego jest Krakowska Kongregacja Kupiecka, założona w 1410 r.. Innymi formami wsparcia były tzw. „banki pobożnych”, udzielające drobnego, bezprocentowego kredytu pod zastaw (jeden z pierwszych banków został założony w Krakowie w 1585 r. z inicjatywy ks. Piotra Skargi).

Niektóre zgromadzenia zakonne miały i nadal mają działalność społeczną wpisaną w swoją regułę: tercjarze - zaangażowani w niesienie pomocy potrzebującym, lazaryści - sprawujący opiekę nad chorymi, trynitarze - opiekujący się więźniami, i inne zakony [Radwan-Pragłowski, Frysztacki, 1998, s. 109 i dalej].

Do końca XVIII w. samopomoc społeczna była organizowana i koordynowana przez właścicieli dóbr, które miały być chronione. Dopiero na przełomie XVIII i XIX w. na ziemiach polskich zaboru pruskiego zaczęły powstawać pierwsze towarzystwa ogniowe o charakterze publiczno-prawnym, zwane socjetami. Celem socjet było „wspólne ponoszenie szkód, utrzymanie dobrego bytu i sposobu życia mieszkańców miast i wsi, zabezpieczanie ich własności oraz odbudowa zniszczonych lub uszkodzonych pożarem budynków" [Sangowski, 2001, s. 42].

Okres zaborów otwiera tradycję niepodległościową w tworzeniu organizacji samopomocowych i łączeniu nurtu filantropijnego z niepodległościowym (np. dzieła Stanisława Staszica, inicjatora lub współtwórcy wielu przedsięwzięć społeczno-gospodarczych, m.in.: Towarzystwa Przyjaciół Nauk, Komisji Edukacji Narodowej, Uniwersytetu Warszawskiego, korporacji (izb) rękodzielniczych, handlowych, górniczych, Towarzystwa Rolniczego Hrubieszowskiego - wspólnoty, zarządzanej przez chłopów, mieszkańców dóbr, którym rozdzielono ziemię (nie dając na własność) i określono działania samopomocowe na wypadek urodzaju i nieurodzaju, tworząc wspólną kasę zapomogową i bank pożyczkowy, nie zapominając o niepełnosprawnych). Wyrazem tego nurtu było założenie w I połowie XIX w., z inicjatywy Karola Marcinkiewicza, Bazaru Poznańskiego dla polskich kupców, oraz banków ludowych, celem uniknięcia lichwy i udostępnienia kapitału (ks. Augustyn Smarzewski i ks. Piotr Wawrzyniak).

Pierwotne formy spółdzielczości, towarzystw wzajemnościowych, pomocowych były oparte na lokalnych społecznościach, połączonych więzią i osobistą znajomością, zaufaniem, solidaryzmem grupy, mających swe odzwierciedlenie w zasadach „dobrowolnego i otwartego członkostwa", niskich i nieoprocentowanych udziałów, zasadzie „zwrotu od zakupów” czy „jeden członek jeden głos". Przykładem takich inicjatyw były: pierwsza w świecie spółdzielnia w Rochdale w Anglii (1844), spółdzielnie kredytowe Hermana Schulzego z Delitsch (działające w środowisku miejskim: rzemieślni- 
czym), czy kasy Wilhelma Reiffaisena (działające głównie w środowisku wiejskim).

W II połowie XIX wieku nastąpił rozwój form samopomocowych kredytowych i ubezpieczeniowych (towarzystwa ubezpieczeń wzajemnych, Kasy Stefczyka, powstające od 1890 r., spółdzielnie mleczarskie i spożywcze). Koniec XIX w. był rozkwitem spółdzielczości branżowej. Teoretycznym tego wyrazem były koncepcje programu syndykalno-kooperatywnego „rzeczpospolitej spółdzielczej” Edwarda Abramowskiego, proponującego stworzenie ruchu spółdzielczego, w którym czołowe miejsce zajmuje solidarność, jako zasada życia, którą należy realizować przez tworzenie podmiotów pomocy wzajemnej i rozwój sieci samorządów jako obiektów polityki społecznej. Jego zdaniem, kooperatywa jest zbiorem ludzi połączonych pracą i wspólnymi potrzebami, prowadząca własną politykę społeczną, opierająca się na aktywności członków. Jednocześnie Abramowski neguje rolę państwa w przemianach, reprezentując ruch anarchistyczno-socjalistyczny [Abramowski, 1907].

Okres II Rzeczpospolitej to czas konsolidacji trzech różnych systemów polityki społecznej i działalności społecznej. W 1939 r. istniało w Polsce 1.545 fundacji o profilu leczniczym i opiekuńczym.

Po II wojnie światowej dekretem z 1952 r. zlikwidowano fundacje, a ich majątek skonfiskowano, kreując ideę socjalistycznego państwa opiekuńczego. Z końcem lat 70. XX w. powstało na bazie społecznego niezadowolenia „drugie państwo", które doprowadziło do powołania ruchów społecznych: Komitetu Obrony Robotników (KOR) i NSZZ "Solidarności" przy współpracy kościoła katolickiego. Okres 1980-1989 jest czasem przejściowym poprzedzającym transformację, z silnymi wpływami i wzorcami zagranicznymi.

Lata 1989-1992 są latami najbardziej dynamicznymi dla rozwoju organizacji społecznych w Polsce, lecz jest to jednocześnie okres „prób i błędów (liczba fundacji zwiększyła się z 277 do 3.007. Powstało też wówczas 23.138 stowarzyszeń). Był to - jak określano - „baby boom", z typowymi chorobami wieku dziecięcego: brakiem kooperacji, improwizacją, akcyjnością, brakiem reguł, konfliktami, nadużyciami i patologiami. „Boom” inicjatyw społecznych w ówczesnych latach miał miejsce w warunkach żywiołowości, wysokiej inflacji i braku podstaw systemowo-strukturalnych. Sektor pozarządowy w latach 90. dystansował się od działalności rządu (spuścizna po alienacji we wcześniejszym okresie); rząd również, mimo oficjalnego poparcia, nie wspierał technicznie jego działań [Gliński, Palska, 1997, s. 376 i dalej]..

Podstawy prawno organizacyjne i systemowe ekonomii społecznej zostały tworzone stopniowo w latach 90. XX wieku i trwają do chwili obecnej.

\section{Koncepcje polityki społecznej państwa - rys historyczny, systematyka}

Równolegle do przedsięwzięć społecznych rozwijały się koncepcje polityki społecznej państwa, które na gruncie teorii politycznych, socjologicznych, ekonomicznych i mieszanych, wyjaśniały funkcje i znaczenie państwa w rozwiązywaniu problemów społecznych. Ich ogólną systematykę zawiera tabela $1^{2}$.

\subsection{Koncepcje społecznej funkcji państwa w teoriach politycznych}

Do końca XVII w. ład społeczny wyjaśniano wpływami Boga i przypisanym miejscem grup i jednostek w strukturze społecznej. Podstawą nowego ładu społecznego zapoczątkowanego w XVII w. była wolność jed-

\footnotetext{
2 Inne ujęcie koncepcji i intelektualnych korzeni ekonomii społecznej przedstawiają tezy przedstawione przez: B. Szopę w zakresie teorii ekonomicznych [Szopa, 2012], J. Filek - w zakresie teorii filozoficznych [Filek, 2012], M. Jelonek - w zakresie teorii socjologicznych [Jelonek, 2012] zawarte w: [Frączek, Hausner, Mazur, 2012].
} 
Tabela 1. Przegląd koncepcji polityki społecznej państwa

\begin{tabular}{|c|c|}
\hline Systematyka & Teorie, koncepcje, wdrożenia \\
\hline \multirow{6}{*}{ Teorie polityczne } & Ład społeczny, umowa społeczna \\
\hline & $\begin{array}{l}\text { Liberalizm gospodarczy i jego nurty: leseferyzm, liberalizm demokratyczny, } \\
\text { liberalizm konserwatywny, liberalizm socjalny }\end{array}$ \\
\hline & Państwo opiekuńcze (welfare state), społeczna gospodarka rynkowa \\
\hline & Państwo socjalistyczne \\
\hline & Teorie konsensusu konstytucyjnego i niedoskonałości rządu \\
\hline & Państwo i społeczeństwo obywatelskie \\
\hline \multirow{2}{*}{ System zabezpieczenia społecznego } & System ubezpieczeń społecznych \\
\hline & System zaopatrzenia i opieki społecznej \\
\hline \multirow{6}{*}{ Teorie socjologiczne } & Teorie wspólnot \\
\hline & Teorie zrównoważonego rozwoju społecznego \\
\hline & Teorie pluralizmu instytucji w obszarze społecznym \\
\hline & Teoria dóbr publicznych i dóbr prywatnych \\
\hline & Teoria pomocniczości (subsydiarności) \\
\hline & Teorie efektów zewnętrznych i kosztów społecznych gospodarowania \\
\hline \multirow{4}{*}{ Ekonomia społeczna } & Teorie podażowe (kooperatywizm, idea wzajemności) \\
\hline & Teorie popytowe (socjalizm, kooperatywizm i inne) \\
\hline & Teoria zawodności rynku w zaspokajaniu potrzeb społecznych \\
\hline & Model aktywnej polityki społecznej państwa \\
\hline Biznes & Społeczna odpowiedzialność biznesu \\
\hline
\end{tabular}

Źródło: opracowanie własne.

nostki i umowa społeczna (przedstawicielami tego nurtu byli: T. Hobbes, J. Locke, D. Hume, J.J. Rousseau, I. Kant).

Podstawą politycznych teorii ładu społecznego były teorie umowy społecznej, które ewoluowały w toku dziejów i funkcjonują do czasów współczesnych. Istotą teorii umowy społecznej jest legitymacja istnienia i działania państwa w wyniku zgody indywidualnych członków społeczeństwa ze względu na ich interes, uświadomiony w procesie historycznym i doświadczeniu społecznym [Golinowska, 1994, s. 11]. Głównym doświadczeniem społecznym były skutki działania mechanizmu rynkowego: wykluczenie i petryfikacja nierówności społecznych. Wolność jednostki - podstawowa wartość liberalnych koncepcji - musi zostać ograniczona, kiedy zagraża wolności innych członków spo- łeczeństwa. Ograniczenie to polega na ustanowieniu pewnych reguł, które jednostki zgodnie będą respektować. Przykładem umowy społecznej jest system zabezpieczenia społecznego.

W ramach koncepcji umowy społecznej różnie definiowano zakres oddziaływania państwa na procesy społeczne. W koncepcjach liberalnych (z łaciny liberalis - dotyczący wolności, od liber - wolny) zakładano ograniczenie funkcji państwa w sferze gospodarki i poszerzenie zakresu wolności jednostki. U podstaw powstałej na przełomie XVII i XVIII w. teorii leżą: indywidualizm, nadrzędność jednostki nad społeczeństwem, wolność człowieka, prawo do zdobywania własności, swoboda działalności gospodarczej, ograniczenie roli państwa do ustanowienia reguł, które podmioty biznesu muszą respek- 
tować (roli „nocnego stróża”). Mechanizm rynkowy w tych koncepcjach jest podstawą alokacji dóbr, a prawa natury - normami regulującymi życie wszystkich ludzi. Za prekursorski, w dziedzinie formowania koncepcji liberalizmu, uważa się dorobek intelektualny T. Hobbesa, B. Spinozy, J. Locka, J.J. Rousseau. Za twórcę teorii ekonomicznego liberalizmu uznawany jest A. Smith, a jego zasady wprowadzone zostały w Stanach Zjednoczonych i w większości państw europejskich pod koniec XIX w. ${ }^{3}$ Na przełomie XIX i XX w. narodził się tzw. liberalizm socjalny, jako rezultat krytyki założeń klasycznego liberalizmu politycznego i ekonomicznego, zwłaszcza jego radykalnego nurtu - leseferyzmu ${ }^{4}$. Po II wojnie światowej liberalizm podzielił się na dwa nurty: liberalno-demokratyczny, głoszący m.in. idee wolności i równouprawnienia wszystkich jednostek, demokratyzacji systemu politycznego, konkurencyjności partii politycznych, upowszechnienia bezpłatnej, laickiej oświaty, rozdziału Kościoła od państwa oraz liberalizm konserwatywny (realizowany m.in. przez M. Thatcher czy R. Reagana), który minimalizował zakres polityki społecznej państwa, przenosząc akcent na rodzinę oraz instytucje rynkowe, co wywoływało problemy polityczne.

Krytyka założeń liberalizmu politycznego i ekonomicznego wykształciła nurt socjalny, którego podstawą była polityka interwencjonizmu państwowego (aktywnego oddziaływania państwa na przebieg procesów gospodarczych) i teoria państwa opiekuńczego.

Teoria państwa dobrobytu (welfare state) została ukształtowana po II wojnie światowej w krajach Europy Zachodniej. Zakłada ona następujące zadania państwa:

\footnotetext{
3 Najwybitniejszymi przedstawicielami liberalizmu byli m.in.: w Anglii - J.S. Mill, a we Francji - A. de Tocqueville.

4 "Laissez faire", leseferyzm - system poglądów ekonomicznych i oparty na jego zasadach typ polityki gospodarczej, których fundamentem jest całkowita neutralność państwa i innych organizacji gospodarczych i politycznych wobec przebiegu procesów gospodarczych.
}

1. W sferze społecznej: rozszerzanie systemu świadczeń i ochrony socjalnej (np. ubezpieczenia na wypadek choroby, kalectwa, bezrobocia), zagwarantowanie wszystkim obywatelom dochodów minimalnych i równych praw w dostępie do usług socjalnych (np. mieszkania, wykształcenia, opieki zdrowotnej).

2. W sferze ekonomicznej: ingerencja państwa w życie gospodarcze w zakresie pobudzania gospodarki, utrzymywania pozytywnych tendencji, zwalczania inflacji i bezrobocia.

3. W sferze ustroju politycznego: demokracja oraz likwidacja wszelkich form politycznej dyskryminacji (np. kobiet, mniejszości etnicznych, mniejszości seksualnych).

Realizacja tych założeń miała umożliwić stworzenie sprawiedliwego społeczeństwa i osiągnięcie powszechnego dobrobytu przy zachowaniu podstaw systemu kapitalistycznego. Państwo dobrobytu powinno być kompromisem pomiędzy pracodawcą i pracownikiem, wzrostem gospodarczym a sprawiedliwym i równym podziałem dóbr. Koncepcję państwa opiekuńczego realizowano m.in. w krajach skandynawskich (przede wszystkim w Szwecji) i w Niemczech. Za czołowych twórców idei państwa opiekuńczego uważani są G. Myrdal i E. Wigfors (Szwecja) oraz J.K. Galbraight i J. Rawls (Stany Zjednoczone).

Polityka społeczna państwa miała szczególne i dominujące miejsce w teorii i praktyce państwa socjalistycznego ${ }^{5}$. Głównymi teo-

\footnotetext{
Socjalizm utopijny tylko w nurcie odwoływania się do dobrej woli, filantropii i tworzenia wspólnotowych przedsięwzięć społeczno-gospodarczych jako przeciwwagi dla wyzysku kapitalistycznego podejmował problematykę zbieżną ze współczesną koncepcją trzeciego sektora. Przedstawicielami tego nurtu, oprócz R. Owena, są: H. de Saint Simon, Ch. Fourier, twórca terminu "feminizm" i zwolennik większego dostępu kobiet do życia społeczno-politycznego (od 1808 r.), a w Polsce Z. Świętosławski. Ideę sprawiedliwości społecznej przez poddanie całej gospodarki kontroli społecznej i politycznej głosili również i wdrażali w życie przedstawiciele tzw. socjalizmu realnego (K. Marks, F. Engels, P. Proudhon, M. Bakunin, W. Lenin). Nurtami sprzecznymi z koncepcją trzeciego sektora było
} 
retykami socjalizmu byli: K. Marks, F. Engels, W.I. Lenin. Teorie socjalizmu zostały wprowadzone do praktyki w Związku Radzieckim po rewolucji październikowej w 1917 roku oraz po II wojnie w krajach Europy Wschodniej (w tym w Polsce). Podstawą funkcjonowania państwa socjalistycznego było stymulowanie sprawiedliwości społecznej przez alokację redystrybucyjną państwa, ograniczony zakres funkcjonowania mechanizmu rynkowego, dominującą rolę państwa i marginalizowanie roli jednostki, własności prywatnej, indywidualnej przedsiębiorczości.

W tym ustroju społeczno-gospodarczym funkcje sektora ekonomii społecznej pełniło głównie państwo. Koncepcja państwa socjalistycznego, z rozbudowanymi roszczeniami społecznymi obywateli, zaczęła stanowić istotne zagrożenie dla systemu finansów publicznych, obciążonych nadmiernymi wydatkami socjalnymi kosztem wydatków prorozwojowych (np. Polska miała relatywnie wyższe wskaźniki udziału rencistów i inwalidów w społeczeństwie). Nadmierna dominacja równości i swoiście pojmowanej sprawiedliwości w praktyce państw socjalistycznych osłabiła efektywność stymulowaną przez mechanizm rynkowy (który był w tym ustroju marginalizowany) i stała się $w$ rezultacie zagrożeniem dla wzrostu produktu społecznego brutto, rozwoju i innowacyjności, powodując upadek państw socjalistycznych i ich transformację gospodarczą w kierunku „urynkowienia”.

\section{Teorię konsensusu konstytucyjnego} jako rodzaj umowy społecznej rozwinął J.M. Buchanan [1975]. W swych publikacjach naukowych, w kontekście dyskusji nad ekonomiczną rolą państwa, starał się udowodnić, że dobro publicznie nie jest jedynym motywem działania polityków i urzędników reprezentujących państwo, że starają się oni maksymalizować także własne cele,

odrzucenie przez socjalistów rynku jako regulatora głównych procesów gospodarczych oraz postulat zniesienia prywatnej własności. w dużym stopniu niezależnie od preferencji i oczekiwań społeczeństwa (jedna z teorii zawodności kontraktu). Dlatego postulował nałożenie konstytucyjnych ograniczeń na zachowanie osób urzędowych, zwłaszcza pochodzących z wyboru, w celu wyeliminowania ich działania we własnym interesie, a zwiększenia poczucia obowiązku i odpowiedzialności wobec społeczeństwa. Za dorobek w tym zakresie otrzymał w 1986 r. Nagrodę Nobla.

Koncepcja niedoskonałości rządu (government failure) wskazuje na ułomność demokracji w spełnianiu oczekiwań wszystkich obywateli dotyczących dóbr publicznych i ograniczoność środków publicznych (efekt „krótkiej kołdry”). Państwo bowiem zawsze w realizacji polityki społecznej działa w warunkach licznych ograniczeń, wyznaczonych poziomem rozwoju społeczno-gospodarczego (dobrobytu).

Ideę społeczeństwa obywatelskiego w ramach której skonstruowany jest model ekonomii społecznej - sformułował V. Havel twierdząc, że „społeczeństwo obywatelskie, może najpełniej pomóc państwu w samorealizacji jednostki i społeczności" [Havel, 1992, s. 84-90]. Wartości społeczeństwa obywatelskiego są stymulowane przez prawo (poprzez demokrację, równouprawnienie), gospodarkę (poprzez zrównoważony rozwój społeczno-gospodarczy, solidaryzm społeczny), instytucje i organizacje (poprzez partie polityczne, grupy religijne, stowarzyszenia pomocowe, związki zawodowe, instytucje społeczne, gwarancyjne państwa) [Skąpska, 2007, s. 49-59].

\subsection{System zabezpieczenia społecznego}

System zabezpieczenia społecznego to gwarantowany konstytucyjnymi zapisami oraz organizowany i koordynowany przez państwo podstawowy element powszechnego zabezpieczenia społecznego obywateli o charakterze roszczeniowym. Dopiero reformy społeczne O. Bismarcka, zainicjowane 
w $1881 r^{6}{ }^{6}$ stworzyły rozwiązania systemowe problemów społecznych o charakterze powszechnym, roszczeniowym, których koordynatorem i gwarantem było państwo i stąd datę tę przyjmuje się jako początek realizacji aktywnej polityki społecznej państwa.

W Polsce ${ }^{7}$ gwarancje zabezpieczenia społecznego zawarte są w art. 67 Konstytucji, który stanowi, iż obywatel ma prawo do zabezpieczenia społecznego $\mathrm{w}$ razie niezdolności do pracy ze względu na chorobę lub inwalidztwo oraz po osiągnięciu wieku emerytalnego.

Główną formą zabezpieczenia społecznego jest system ubezpieczeń społecznych. Cechami wyróżniającymi ten system są: finansowanie oparte na składce pracowniczej, przymusowość, wzajemność, realizacja celów społecznych, powszechność, równe traktowanie ubezpieczonych, państwowe gwarancje wypłacalności świadczeń do poziomu zdefiniowanego minimum socjalnego lub w zdefiniowanych przypadkach losowych.

Uzupełniającym filarem zabezpieczenia społecznego są: system zaopatrzenia społecznego - nieskładkowy, finansowany z budżetu państwa (dotyczy niektórych grup społeczno-zawodowych) o charakterze roszczeniowym, oraz system pomocy (opieki) społecznej - nieskładkowy, o charakterze uznaniowym, dotyczący wszystkich obywateli, którzy z określonych przyczyn losowych nie są w stanie sami zapewnić sobie minimum egzystencji.

6 W tym roku cesarz Wilhelm I wygłosił orędzie zapowiadające stworzenie systemu ubezpieczenia społecznego w Niemczech. W latach 1883, 1994 i 1889 O. von Bismarck wprowadził ustawy o ubezpieczeniu na wypadek choroby, wypadków przy pracy, ubezpieczeniu rentowym na starość i na wypadek inwalidztwa. Założenia te zostały rozszerzone na inne kraje europejskie i świat, a z pewnymi modyfikacjami funkcjonują do chwili obecnej, znane jako bismarckowski model repartycyjny ubezpieczeń społecznych [więcej w: Muszalski, 2004, s. 36-39].

Na gruncie międzynarodowego prawa zabezpieczenia społecznego wyróżnia się akty Organizacji Narodów Zjednoczonych (Powszechna Deklaracja Praw Człowieka, Międzynarodowy Pakt Praw Ekonomicznych, Socjalnych i Kulturalnych, Konwencja MOP o minimalnych normach zabezpieczenia społecznego) oraz Rady Europy (Europejska Karta Socjalna), których sygnatariuszem jest również Polska.
System zabezpieczenia społecznego funkcjonuje jedynie w gospodarkach rozwiniętych, a jego zakres jest zróżnicowany w zależności od przyjętej koncepcji społecznej państwa oraz możliwości budżetu, którego wydatki na ten cel mają charakter sztywny w ramach koncepcji społecznej funkcji państwa oraz przyjętego konsensusu społecznego.

\subsection{Koncepcje społecznej funkcji państwa w teoriach socjologicznych}

Zakres społecznej funkcji państwa wynika z umowy społecznej, w której mechanizm politycznych negocjacji i demokratycznych procedur wyboru przenosi się na wybory celów socjalnych i sposobów ich realizacji w wyborach politycznych. Współcześnie umowa społeczna oznacza konsensus między różnymi grupami społecznymi, którego podstawowe zasady zawarto w konstytucji, a polityka społeczna państwa jest elementem programu partii politycznych i podlega weryfikacji przez społeczeństwo w demokratycznych wyborach powszechnych. Rola państwa w pełnieniu funkcji socjalnej $w$ ramach umowy społecznej może być zróżnicowana i ma swój wyraz w podstawowych prawach obywatelskich, zawartych w konstytucji i innych aktach normatywnych oraz w przyjętych rozwiązaniach systemowych (np. ochrona zdrowia, polityka społeczna, system oświaty, polityka kulturalna itp.). Na tym tle ukształtowały się różne modele polityki społecznej państwa.

Z koncepcji welfare state rozwinęła się w Niemczech Zachodnich koncepcja społecznej gospodarki rynkowej, która stanowiła połączenie gospodarki rynkowej i wysokiego poziomu zabezpieczenia socjalnego pracowników. Bezpośrednim celem społecznej gospodarki rynkowej było zapewnienie pełnego zatrudnienia, wspieranie regionalnej mobilności siły roboczej, ochrona pracy przez regulację stosunku pracy między pracodawcą a pracownikiem. Narzędziami polityki państwa były: ustalanie płacy minimalnej, wy- 
sokie podatki przy zapewnieniu całościowej ochrony socjalnej (ubezpieczenie społeczne, zwrot kosztów leczenia itd.), niskie ceny na artykuły pierwszej potrzeby (polityka subwencji wobec producenta), rozwój szkolnictwa publicznego na wysokim poziomie itd. Niemcy Zachodnie, prowadząc przez lata taką politykę, doprowadziły do szybkiego rozwoju gospodarczego, zachowując dużą ochronę socjalną. System ten zaczął się jednak załamywać po zjednoczeniu, ze względu na różnice w rozwoju gospodarczym obu części Niemiec [więcej w: Smolski, Smolski, Stadtmüller, 1999].

Społeczna gospodarka rynkowa (SGR) zainspirowała twórców nowego systemu gospodarki w Polsce po okresie transformacji z lat 1989-1990 do tego stopnia, że została wpisana do Konstytucji Rzeczypospolitej Polskiej jako podstawa jej ustroju gospodarczego. Dokładny zapis artykułu 20 Konstytucji RP brzmi następująco: „Społeczna gospodarka rynkowa oparta na wolności działalności gospodarczej, własności prywatnej oraz solidarności, dialogu i współpracy partnerów społecznych stanowi podstawę ustroju gospodarczego Rzeczypospolitej Polskiej"8. Sformułowanie to nie oznacza jednakże, że SGR jest ustrojem gospodarczym w Polsce, lecz stanowi jego formalno-prawną podstawę. Faktycznie ustrój gospodarczy w Polsce rozwinął się w kierunku gospodarki rynkowej, wraz z jej pozytywnymi i negatywnymi skutkami ekonomicznymi oraz społecznymi. Swoboda działalności gospodarczej w warunkach gospodarki rynkowej opartej na mechanizmie konkurencji doprowadziła do marginalizacji i zdefiniowanego przez Hirschmana „wyjścia” niektórych grup społecznych (np. bezrobotni), pojawienia się nowej klasy prekariatu [Standing, 2016], czyli osób pracujących w ciągłej niepewności przyszłości (w oparciu o tzw. „umowy śmieciowe”), bez

8 Konstytucja Rzeczypospolitej Polskiej z dnia 2 kwietnia 1997 r. (Dz.U.1997.78.483) tożsamości zawodowej, lub o wyższych kwalifikacjach, niż wykonywana praca i otrzymywane wynagrodzenie, pozbawionych przywilejów socjalnych, lub otrzymujących wynagrodzenie na podstawie umowy o pracę, lecz w wysokości nie pozwalającej na zapewnienie godnych warunków egzystencji i rozwoju. Prekariuszem można zostać wskutek wypadku losowego (np. choroba, wypadek), własnych lub cudzych błędów życiowych (bankructwo), czy własnego wyboru (niechęć lub brak motywacji do rozwoju zawodowego). W tym kontekście można postawić tezę, że podstawą ustroju gospodarczego w Polsce jest liberalizm gospodarczy, natomiast wspomniany zapis konstytucyjny wymusza podejmowanie działań zarówno w obszarze polityki społecznej, jak również komplementarnie w obszarze ekonomii społecznej. Działania te łączą wspólne cele społeczne (np. harmonijny i zrównoważony rozwój społeczno-gospodarczy, zapobieganie marginalizacji niektórych grup społecznych itp.), lecz występują też istotne różnice między tymi najważniejszymi sektorami, zaangażowanymi w rozwiązywanie problemów społecznych. Zawarte one zostały w tabeli 2.

Reasumując powyższe rozważania można stwierdzić, że przesłanką funkcjonowania polskiego modelu ekonomii społecznej i źródłem jej rozwoju jest ukształtowanie się faktycznego ustroju gospodarki wolnorynkowej i zagwarantowany konstytucyjnie obowiązek minimalizacji jej negatywnych skutków społecznych przez przyjęcie różnych komplementarnych rozwiązań $w$ tym zakresie, do których można zaliczyć - poza wspomnianymi formami działalności - również społeczną odpowiedzialność biznesu (CSR - Corporate Social Responsibility), która jest elementem modelu europejskiej polityki społecznej przejętego w 2000 r. w Strategii Lizbońskiej. Biznes społecznie odpowiedzialny to biznes, który realizując cele ekonomiczne zapewnia właściwe kształtowanie relacji między głównymi interesariuszami (właściciele, pracownicy, me- 
Tabela 2. Podstawowe różnice między ekonomią społeczną a polityką społeczną państwa

\begin{tabular}{|l|l|l|}
\hline \multicolumn{1}{|c|}{ Wyszczególnienie } & \multicolumn{1}{c|}{ Ekonomia społeczna } & \multicolumn{1}{c|}{ Polityka społeczna } \\
\hline Dominujący stosunek własnościowy & własność prywatna & własność publiczna \\
\hline Dominujący sposób alokacji dóbr & rynkowy, nierynkowy & redystrybucyjny \\
\hline Dominujące źródła finansowania & prywatne & publiczne \\
\hline Regulacja kierunków działań i jej charakter & $\begin{array}{l}\text { dowolny, określony w statucie } \\
\text { organizacji }\end{array}$ & $\begin{array}{l}\text { ścisły, określony w ustawie } \\
\text { budżetowej }\end{array}$ \\
\hline Charakter odpowiedzialności przed społeczeństwem & ekonomiczny & polityczny \\
\hline
\end{tabular}

Źródło: opracowanie własne.

nadżerowie, nabywcy, społeczność lokalna), zachowując właściwe proporcje między celami gospodarczymi i społecznymi, zawarte w koncepcji „trzech E” („efektywności, ekonomiczności i etyczności").

Odmienną genezę ma rozwój ekonomii społecznej w innych krajach Europy. Koniec XX w. i początek XXI w. zdominowała dyskusja o kryzysie i kurczeniu się roli państwa opiekuńczego w Europie. Zapoczątkowana na początku lat 80. krytyka państwa opiekuńczego zakładała jego demontaż przez prywatyzację i komercjalizację programów socjalnych. Argumentowano, że „programy socjalne wychowują własnych klientów (koncepcja underclass, czyli środowisk uzależnionych od pomocy społecznej). Do głównych przyczyn kryzysu koncepcji państwa opiekuńczego można zaliczyć:

- zagrożenie systemu finansów publicznych przez nadmierne wydatki socjalne,

- osłabienie roli rynku, motywacji do pracy, inwestowania i oszczędności,

- długofalowe i kumulujące się efekty starzenia się społeczeństw,

- globalizację gospodarki, która weryfikuje mniej efektywne gospodarki oparte na koncepcji państwa opiekuńczego [więcej w: Hausner, Kwiecińska, Pacut, 2008, s. 63-80].

Na tym tle dostrzeżono niewykorzystany kapitał sektora obywatelskiego, a w konsekwencji zaczęto w większym stopniu powierzać wykonywanie zadań publicznych organizacjom pozarządowym, przyczyniając się do ich częściowej komercjalizacji i ekonomizacji (co spowodowało ewolucję sektora od non profit do not for profit) [Kaźmierczak, Rymsza, 2003, s. 22-23].

Efektem tych koncepcji były reformy socjalne w większości państw europejskich w latach 90. XX w., w konsekwencji których przyjęto zasadę pomocniczości państwa, która została najpełniej zoperacjonalizowana w Niemczech przez decentralizację zadań publicznych i zasadę pierwszeństwa organizacji obywatelskich w świadczeniu usług społecznych przy wykorzystaniu środków publicznych. W efekcie zmian nastąpił wzrost znaczenia samorządności lokalnej, zarówno wźkrajach Europy Zachodniej i Północnej, jak też Europy Środkowo-Wschodniej, przechodzących wówczas transformacje systemową. Skutkuje to rozwojem zróżnicowanych form ekonomii społecznej.

Tendencje te w polskim modelu ekonomii społecznej zaczęły być widoczne po wejściu Polski w 2004 r. do Unii Europejskiej i przystąpieniu do realizacji europejskiej polityki społecznej, w ramach której znaczącą rolę przypisano podmiotom ekonomii społecznej. Tym samym sektor ekonomii społecznej został włączony do unijnej a później krajowej polityki społecznej państw członkowskich UE. Wspieranie sektora ekonomii społecznej w ramach programów unijnych wynikało z przekonania o wyższej skuteczności i efektywności aktywnych form polityki społecznej (model „wędki", np. wspieranie tworzenia nowych miejsc pracy) niż jej pa- 
sywnych form (model "ryby", np. zasiłek dla bezrobotnych).

W XXI wieku problemy społeczne, wywołane skutkami transformacji gospodarczej, reform strukturalnych i kryzysu finansowego wywoływały i wywołują społeczną frustrację (np. ruch „oburzonych"), presję roszczeniową i radykalizm ze strony wykluczonych grup społecznych, które prowadzą często do zmian politycznych. Pojawia się - pod wpływem presji społecznej i wyborów politycznych - koncepcja państwa socjalnego z nowymi oczekiwaniami obywateli.

Spośród współczesnych teorii i koncepcji ekonomicznych akcentujących pierwiastki społeczne można wyróżnić opisane poniżej koncepcje funkcjonowania obszarów społecznych.

Teorie wspólnot i nowych ruchów społecznych głoszą, że beneficjentem określonych dóbr jest społeczeństwo w skali globalnej, a nie tylko pewne grupy społeczne (przykładowo takimi ruchami społecznymi o zasięgu globalnym mogą być: ochrona indywidualizmu, wolności człowieka, demokracji, pacyfizm, ochrona środowiska naturalnego, praw człowieka, praw dziecka itp.).

Teoria zrównoważonego rozwoju społeczno-gospodarczego zakłada jego stymulowanie przez państwo w ramach procesów redystrybucyjnych (teorie wzrostu ogólnego dobrobytu, łagodzenia nierówności i eliminacji ubóstwa) i realizację celów społecznych przez łagodzenie nierówności i ustalenie minimum socjalnego. Rola państwa w pełnieniu funkcji socjalnej jest zróżnicowana (zredukowana w nurcie liberalnym, rozwinięta w nurcie socjalnym) i ma swój wyraz w zagwarantowanych podstawowych prawach obywatelskich, oraz w przyjętych rozwiązaniach systemowych (np. ochrona zdrowia, polityka społeczna, system oświaty, polityka kulturalna itp.). Zapewnienie odpowiedniego poziomu polityki społecznej państwa, ustalenie niezbędnego minimum dóbr społecznych wynika z umowy społecznej zawartej w kon- stytucji i wiąże się z obciążeniem wszystkich obywateli i sektora biznesu (podatki, składki na ubezpieczenia społeczne, zdrowotne). Nadmierne obciążenia fiskalne wywołują niezadowolenie społeczne, przejawiające się w protestach czynnych (np. strajki) lub biernych (np. rozwój „,szarej strefy”). Prawidłowość ta jest sformułowana w ekonomii jako krzywa Laffera9 ${ }^{9}$, według której po przekroczeniu pewnej granicy obciążeń fiskalnych wpływy budżetowe spadają. Nadmierne przenoszenie problemów społecznych na obszar polityki państwa może przyczynić się do jego niewydolności i spirali roszczeń o charakterze indywidualnym (np. pomoc społeczna) lub zbiorowym (np. minimalny koszyk świadczeń zdrowotnych). Wsparciem dla polityki społecznej państwa i komplementarnym rozwiązaniem jest rozwój sektora ekonomii społecznej.

Teoria pluralizmu instytucji w obszarze społecznym została rozwinięta przez F.A. Hayeka, który nie negując funkcji socjalnych państwa w ogóle, neguje monopol państwa w rozwiązywaniu kwestii socjalnych. W tej koncepcji konkurencja, która jest motorem postępu i zmian, powinna mieć także miejsce w obszarze społecznym w formie dopuszczania pluralizmu instytucji socjalnych [Hayek, 1981, s. 34-35].

Równoległym obszarem polityki społecznej państwa jest kreowanie dóbr publicznych. Teoria dóbr publicznych i dóbr prywatnych oraz dóbr merytorycznych, sformułowana przez P.A. Samuelsona [1954] i rozwinięta przez małżeństwo R.A. i P. . Musgrave [1973, 1990], oparta jest na założeniu o zawodności rynku i sektora publicznego w zaspokajaniu potrzeb społecznych. Dobra publiczne nie mają rynkowego charakteru wykluczenia, stanowią wartość wspólną (np. środowisko naturalne, kultura, prawa człowieka, pacyfizm), ich beneficjentem jest całe społeczeń-

\footnotetext{
Krzywa Laffera w ujęciu teoretycznym ilustruje związek między skalą opodatkowania a dochodami budżetowymi z tytułu podatków [patrz m.in. Owsiak, 2002, s. 286 i dalej].
} 
stwo, często bywają niepodzielne, możliwa jest ich wspólna konsumpcja. Koordynatorem systemu dystrybucji tych dóbr może być państwo (w ramach dążenia do dobrobytu społecznego), a wykonawcą zadań zleconych - podmioty ekonomii społecznej. Sektor ekonomii społecznej wspiera rozwój tych dóbr publicznych, których wspólna konsumpcja społeczna prowadzi do wyrównywania poziomu życia społeczeństwa i egalitaryzacji. Obszarem polityki społecznej państwa jest również finansowanie dóbr publicznych, które mają charakter wspólnej konsumpcji, lecz dla podmiotów biznesu są nieopłacalne (np. promocja sportu, kultury, zdrowia) [Musgrave, Musgrave, Kulmer, 1990].

Na szczególną uwagę zasługuje wspomniana już teoria pomocniczości (subsydiarności), wywodząca się ze społecznej nauki Kościoła katolickiego, której zasady sformułowano w encyklikach papieży: Leona XII (Rerum novarum z 1890 r.), Piusa XI (Quadragesimo Anno z 1931 r.] i Jana Pawła II (Contessimus Annus z 1991 r.]. Zasada pomocniczości oznacza, że „społeczność wyższego rzędu nie powinna ingerować w wewnętrzne sprawy społeczności niższego rzędu (...), lecz wspierać ją w razie konieczności i pomóc w koordynacji jej działań z działaniami innych grup społecznych dla dobra wspólnego". Zasadę pomocniczości streszczają zdania: „tyle władzy, na ile to konieczne, tyle wolności, na ile to możliwe" oraz "tyle społeczeństwa, na ile to możliwe, tyle państwa, na ile to konieczne" [Hoffner, 1992, s. 38].

Zasada pomocniczości może występować jako:

- pionowa (pomocniczość społeczności nadrzędnych na rzecz podstawowych), wywodząca się z nauki społecznej kościoła,

- pozioma, dotycząca współpracy między organami administracji publicznej a organizacjami pozarządowymi w sferze pożytku publicznego na zasadach suwerenności stron, partnerstwa, efektywności, konkurencji, jawności [lzdebski, 2008, s. 44].
Zasada pomocniczości została podniesiona w Unii Europejskiej do rangi podstawowych zasad społecznych i ostatecznie została włączona do prawa traktatowego Unii Europejskiej.

Pomocniczość państwa wobec sektora ekonomii społecznej wyraża się w udzielaniu mu wsparcia przez:

- współfinansowanie przez państwo i samorządy lokalne programów integracyjnych,

- subsydiowanie zatrudnienia w spółdzielniach i innych podmiotach ekonomii społecznej, realizujących komplementarne cele społeczne państwa,

- zakupywanie przez samorządy lokalne usług i produktów tworzonych przez podmioty ekonomii społecznej.

Ciekawa jest też teoria efektów zewnętrznych, która odnosi się do oddziaływania efektów gospodarczych na inne obszary (zewnętrzne) i oddziaływanie to może mieć charakter pozytywny (np. aktywizacja ludności) lub negatywny (zanieczyszczenie środowiska naturalnego). Oddziaływanie efektów zewnętrznych może być przedmiotem kompleksowej kalkulacji kosztów i korzyści projektów społecznych i jest coraz częściej uwzględniane w projektach ekonomicznych i społecznych.

\subsection{Teorie i praktyka ekonomii społecznej w Polsce}

Komplementarnym wsparciem polityki społecznej państwa jest rozwój sektora ekonomii społecznej. Zasadność funkcjonowania sektora ekonomii społecznej wyjaśniają m.in. teorie popytowe i podażowe.

Teorie popytowe opierają się na rozwiązaniach, w których podmiot ekonomii społecznej organizuje na otwartym rynku sprzedaż i marketing wytworzonych przez siebie produktów (np. spółdzielnie pracy, inwalidów). W Polsce przykładem takich organizacji mogą być: spółdzielnie pracy, inwalidów, Centrala Przemysłu Ludowego i Artystycznego 
- CePeliA, czy Związek Artystów Malujących Ustami i Nogami - AMUN, pensjonat "U Pana Cogito" itp. W modelu tym państwo może wspierać niektóre inicjatywy za pomocą mechanizmów alokacji redystrybucyjnej, jednakże podstawowym mechanizmem alokacji dóbr i wartości jest rynek.

Teorie podażowe podkreślają znaczenie przedsiębiorczości i tworzenia produktów nastawionych na zaspokojenie potrzeb grup społecznych. Nurt ten ma w Polsce długoletnie tradycje i przejawia się w postaci np. zakładania spółdzielni mieszkaniowych, towarzystw ubezpieczeń wzajemnych, przedsiębiorstw społecznych, spółdzielni socjalnych, kas kredytowo-pożyczkowych itp.

Cechą charakterystyczną sektora ekonomii społecznej jest wykorzystanie form alokacji rynkowej i redystrybucyjnej w rozwiązywaniu problemów społecznych. Społeczna wartość sektora ekonomii społecznej w gospodarce narodowej sprawdza się w szczególności w grupach opartych na idei samopomocy i wzajemności oraz w grupach zagrożonych ubóstwem, wyuczoną lub nabytą niezaradnością, społecznym wykluczeniem, marginalizacją. Stymulowanie przedsiębiorczości w tych grupach, choćby w minimalnej formie, zmniejsza skalę potencjalnej patologii społecznej, której skutki odczuwa cała społeczność i wpływa stabilizująco na harmonijny i zrównoważony rozwój gospodarki.

Alokacja redystrybucyjna jest w rozwiniętym społeczeństwie realizowana przez sektor publiczny (budżet, jednostki samorządu terytorialnego) oraz sektor prywatny (dotacje, darowizny lub inne formy działalności społecznej i charytatywnej). Ten typ alokacji jest prosty, lecz jednocześnie petryfikuje obszary niezaradności, postawy roszczeniowe, konflikty na tle rozdziału środków, patologie, nie przynosząc korzystnych zmian jakościowych w długim okresie.

Alokacja rynkowa w obszarze społecznym jest trudniejsza, wymaga wysiłku organizacyjnego, finansowego, wiąże się z ryzykiem go- spodarczym, lecz jednocześnie: nadaje sens działań grupom zagrożonym, eliminuje obszary zagrożone marginalizacją, tworzy nową wartość społeczną, zmniejsza zakres patologii społecznej, przyspiesza i harmonizuje rozwój społeczno-gospodarczy, przynosi korzyści w długim horyzoncie czasowym [patrz więcej w: Płonka, 2007, s. 69-70; Płonka 2009, s. 207-216].

Procesy jakościowe wewnątrz sektora ekonomii społecznej, jakie nastąpiły lub powinny nastąpić, można scharakteryzować następująco:

- od formuły biernego członkostwa do aktywnej przynależności,

- od społecznikostwa do profesjonalizacji,

- od neutralnej pozycji państwa wobec podmiotów ekonomii społecznej do realizacji funkcji wspierającej i kooperującej (np. fundacje, stowarzyszenia, WTZ warsztaty terapii zajęciowej, ZAZ - zakłady aktywizacji zawodowej, CIS - Centra Integracji Społecznej, spółdzielnie socjalne). W poszukiwaniu polskiego modelu ekonomii społecznej można się zgodzić z A. Evers i J.-L. Laville [2004], którzy wyróżnili cztery podstawowe funkcje ekonomii społecznej, postrzegane jako:

1. Kreowanie nowych miejsc pracy dla wybranych grup społecznych, oparte na alokacji rynkowej; w modelu polskim ten typ podmiotów jest tradycyjnym filarem ekonomii społecznej o typie samopomocowym (np. rozwój spółdzielni, towarzystw ubezpieczeń wzajemnych), a ich działalność ekonomizuje politykę społeczną państwa i tworzy dodatkowy rynek pracy.

2. Kompensacja procesów opartych na „zawodności rynku i państwa socjalnego" w celu dostarczania usług socjalnych, szczególnie adresowanych do ludzi zmarginalizowanych lub tych, którym grozi społeczna marginalizacja, w celu umożliwienia im transferu na tzw. pierwszy rynek pracy, zwłaszcza tam, gdzie sektor 
prywatny czy publiczny nie są w stanie zaspokoić potrzeb społecznych (rozwój spółdzielni socjalnych, przedsiębiorstw społecznych, niektórych organizacji pożytku publicznego). Ten sektor oparty jest na alokacji rynkowej i nierynkowej przy wsparciu ze strony państwa i programów Unii Europejskiej.

3. Kreowanie kapitału społecznego w postaci polityki integracji społecznej, spójności, zrównoważonego rozwoju społeczno-gospodarczego różnych grup społecznych, realizowanej przez aktywną politykę społeczną państwa, w którym następuje odchodzenie od prostej alokacji redystrybucyjnej w kierunku polityki aktywizacyjnej, a państwo opiekuńcze jest zastępowane przez państwo inwestycji społecznych. Ten kierunek rozwoju, oparty głównie na alokacji nierynkowej, w warunkach polskich zaczął się rozwijać po wejściu Polski do UE w ramach korzystania $\mathrm{z}$ różnych programów spójności, wspierających ten kierunek polityki społecznej państwa.

4. Wspieranie procesów demokratyzacji, tolerancji, swobód obywatelskich, świadomości społecznej, środowiskowej, jako kierunek rozwijający się w Polsce od okresu transformacji gospodarczej i aktywizujący jednostki oraz grupy społeczne w procesy politycznych decyzji (np. Amnesty International).

\section{Podsumowanie}

Pojęcie „ekonomia społeczna” jest współczesne, jednak idea i praktyka „przedsiębiorczości społecznej" sięgają początku dziejów ludzkości (idea solidaryzmu grupy, wzajemności). W przeciwieństwie do współczesnych rozwiązań, teoria i praktyka przedsięwzięć społecznych miały do drugiej połowy XIX wieku charakter partykularny, dobrowolny i uznaniowy (chroniły interes grupy zawodowej, społeczności lokalnej lub miały charakter pojedynczych akcji charytatywnych). Dopiero re- formy O. Bismarcka zapoczątkowane w $1881 \mathrm{r}$. stały się zalążkiem rozpatrywania polityki społecznej państwa jako rozwiązania systemowego, o charakterze roszczeniowym dla społeczeństwa, gwarantowanego przez państwo. Zakres polityki społecznej poszczególnych państw w XX w. i obecnie był i jest zróżnicowany, zależny od przyjętej koncepcji politycznej, społecznej, uwarunkowań specyficznych i tradycji, lecz implikował rozwój ekonomii społecznej, traktowanej jako komplementarne wsparcie polityki społecznej państwa.

Polski model ekonomii społecznej ma specyficzną genezę, charakterystyczną dla krajów środkowoeuropejskich - wyrósł na gruzach gospodarki socjalistycznej, która ukształtowała model redystrybutywny i monopol państwa w rozwiązywaniu problemów społecznych. Funkcjonujący przez ponad 40 lat model gospodarki socjalistycznej ukształtował postawy roszczeniowe społeczeństwa względem państwa (głównie w sferze społecznej), a w przypadku braku ich zaspokojenia - frustrację społeczną. Specyficzna mentalność obywateli ukształtowana w efekcie funkcjonowania w takim państwie wyraża się w pojęciu homo sovieticus, upowszechnionym przez ks. J. Tischnera. Od początku lat 90. XX w. zaczęło się „doganianie” przez Polskę rozwiniętych krajów UE, wraz z ich wadami i zaletami oraz adaptowanie niektórych rozwiązań (w tym m.in. modelu ekonomii społecznej) do polskich realiów.

Główną przesłanką znaczenia i rozwoju ekonomii społecznej - zarówno w Polsce, jak i w innych krajach - jest niedostateczna efektywność państwa w realizacji polityki społecznej opartej na alokacji redystrybucyjnej oraz niedoskonałość i zawodność rządów w rozwiązywaniu problemów społecznych, wynikająca z ich uzależnienia się od wyborów politycznych. Brak zaufania do rządu generuje rozwój organizacji pozarządowych, nieskażonych wyborami politycznymi.

Konkludując rozważania dotyczące tendencji rozwoju sektora ekonomii społecznej 
w Polsce można stwierdzić, że uczestniczy on W realizacji aktywnej polityki społecznej i programów społecznych państwa (model „wędki"), którą cechują:

- budowa sektora ekonomii społecznej jako komplementarnego dla polityki społecznej,

- przesuwanie administrowania socjalnym sektorem publicznym ze szczebla centralnego na szczeble regionalne i lokalne,

- dopuszczanie do środków publicznych niezależnych i prywatnych instytucji o konkurencyjnym charakterze (pluralizm instytucji społecznych),

- odchodzenie od prostej alokacji redystrybucyjnej w kierunku polityki aktywizacyjnej - państwo opiekuńcze powinno zostać zastąpione przez państwo inwestycji społecznych,

\section{Literatura}

Abramowski E. (1907). Idee społeczne kooperatyzmu. Znaczenie spółdzielczości dla Polski. Warszawa.

Buchanan J.M. (1975). The Limits of Liberty. Between Anarchy and Leviathan. Chicago, London: The University of Chicago Press.

Filek J. (2012). "Teorie filozoficzne a ekonomia społeczna", w: M. Frączek, J. Hausner, S. Mazur (red.), Wokół ekonomii społecznej. Kraków: MSAP UEK.

Frączek M., Hausner J., Mazur S. (red.) (2012). Wokół ekonomii społecznej. Kraków: MSAP UEK.

Gliński P., Palska H. (1997). "Cztery wymiary społecznej aktywności obywatelskiej", w: H. Domański, A. Rychard (red.), Elementy nowego ładu. Warszawa: IFiS PAN.

Golinowska S. (1994). Polityka społeczna państwa w gospodarcze rynkowej. Studium ekonomiczne. Warszawa: Wydawnictwo Naukowe PWN.

Evers, A. Laville, J.-L. (2004). „Defining the third sector in Europe", w: A. Evers, J.-L. Laville (red.), The Third Sector in Europe. Cheltenham, UK: Edgard Elgar.

Hausner J. (2008). „Ekonomia społeczna jako kategoria rozwoju", w: J. Hausner (red.), Ekonomia społeczna a rozwój. Kraków: MSAP UEK.

Hausner J., Kwiecińska D., Pacut A. (2008). „Przyszłość państwa opiekuńczego", w: J. Hausner (red.), Ekonomia społeczna a rozwój. Kraków: MSAP UEK.

Havel V. (1992). Summer Meditations on Politics, Morality and Civility in a time of Transition. London: Faber and Faber.
- odejście od opiekuńczej roli państwa w kierunku państwa inwestycji społecznych,

- rozwój pomocniczości państwa, dialogu obywatelskiego, budowanie społeczeństwa opartego na wiedzy zgodnie z zasadą: „od państwa opiekuńczego do opiekuńczego społeczeństwa".

Niezależnie od przyjętej koncepcji polityki socjalnej państwa, w miarę wzrostu zamożności społeczeństwa, a tym samym i państwa, oczekiwania społeczne są zawsze większe, niż dostępne środki na ich zaspokojenie. Między innymi ten powód jest przesłanką rozwoju sektora ekonomii społecznej, który posługując się metodami alokacji rynkowej w realizacji misji społecznej, dąży przede wszystkim do eliminacji fundamentalnych przyczyn, a w dalszej kolejności do walki ze skutkami problemów społecznych.

Hayek F.A. (1981). Die Verfassung einer Gesellschaft freier Menschen. Munchen: Verlag Moderne Industrie.

Hirschman A. (1995). Lojalność, krytyka, rozstanie: reakcje na kryzys państwa, organizacji i przedsiębiorstwa. Kraków-Warszawa: Znak.

Hoffner J. (1992). Chrześcijańska nauka społeczna. Kraków: WAM.

Izdebski H. (2008). „Elementy teorii państwa”, w: J. Hausner (red.), Ekonomia społeczna a rozwój. Kraków: MSAP UEK.

Jelonek M. (2012). „Teorie socjologiczne a ekonomia społeczna", w: M. Frączek, J. Hausner, S. Mazur (red.), Wokół ekonomii społecznej. Kraków: MSAP UEK.

Juran J.M., Gryna F.M. (1988). Juran's Quality Control Handbook. New York: McGraw-Hill.

Kaźmierczak T. Rymsza M. (red.) (2003). W strone aktywnej polityki społecznej. Warszawa: Instytut Spraw Publicznych.

Konstytucja Rzeczypospolitej Polskiej z dnia 2 kwietnia 1997 r (Dz.U. 1997.78.483).

Leś E. (2000). Od filantropii do pomocniczości. Studium porównawcze rozwoju i działalności organizacji społecznych. Warszawa: Dom Wydawniczy ELIPSA.

Musgrave R.A., Musgrave P.B. (1973). Public Finance in Theory and Practice. New York: McGraw-Hill.

Musgrave R.A., Musgrave P.B., Kulmer L. (1990). Die offentlichen Finanzen in Theorie und Praxis. Tubingen: Mohr

Muszalski W. (2004). Ubezpieczenia społeczne. Podręcznik akademicki. Warszawa: Wydawnictwo Naukowe PWN. 
Owsiak S. (2002). Podstawy nauki finansów. Warszawa: Polskie Wydawnictwo Ekonomiczne.

Płonka M. (2007). „Instytucje ekonomii społecznej jako podmioty rynkowe", w: D. Surówka-Marszałek (red.), Marketing, Acta Academiae Modrevianae. Kraków: Krakowskie Towarzystwo Edukacyjne sp. z o.o. - Oficyna Wydawnicza AFM.

Płonka M. (2009). „Sektor ekonomii społecznej, jego miejsce i funkcje w gospodarce rynkowej", w: D. Surówka-Marszałek (red.), Marketing, Acta Academiae Modrevianae. Kraków: Krakowskie Towarzystwo Edukacyjne sp. z o.o. - Oficyna Wydawnicza AFM.

Radwan-Pragłowski J., Frysztacki K. (1998). Społeczne dzieje pomocy człowiekowi; od filantropii greckiej do pracy socjalnej. Katowice: Wydawnictwo Śląsk.

Samuelson P.A, Nordhaus W.D., (1989). Economics. New York: Mc Graw-Hill.
Samuelson P.A. (1954). "The Pure Theory of Public Expenditure", Review of Economics and Statistics, nr 36.

Sangowski T. (red.) (2001). Towarzystwa ubezpieczeń wzajemnych w polskim systemie ubezpieczeń (stan i perspektywy). Poznań: Wydawnictwo AE w Poznaniu. Skąpska G. (2008). „Społeczeństwo obywatelskie: kontekst i płaszczyzny funkcjonowania", w: J. Hausner (red.). Ekonomia społeczna a rozwój. Kraków: MSAP UEK.

Smolski R., Smolski M., Stadtmüller E.H. (1999). Słownik Encyklopedyczny Edukacja Obywatelska. Warszawa: Wydawnictwo Europa.

Standing G. (2016). Prekariat. Nowa niebezpieczna klasa. Warszawa: Wydawnictwo Naukowe PWN.

Szopa B. (2012). „Teorie ekonomiczne a ekonomia społeczna", w: M. Frączek, J. Hausner, S. Mazur (red.), Wokół ekonomii społecznej. Kraków: MSAP UEK.

\section{Social economy vs. concepts of social policy. Polish model}

Summary: The place of social economy is situated within the triangle: the state - market - civil society. The aim of this article is to determine the place of social economy against the background of the social policy of the state.

The article, based on a historical analysis, is an overview of the key concepts of social policy of the state (of the liberal social), and determined the importance of the social economy in solving social problems in contemporary reality in Poland. The conclusion was that the social economy is complementary to the state social policy, operate in conditions of market allocation or redistribution, shows a trend from passive to active support.

Keywords: social economy, social state, social security, corporate social responsibility.

\section{Prawa autorskie i licencja / Copyright and License}

Artykuł opublikowano na licencji Creative Commons

Uznanie autorstwa - Użycie niekomercyjne - Bez utworów zależnych 3.0 Polska http://creativecommons.org/licenses/by-nc-nd/3.0/pl/

This article is published under the terms of the Creative Commons

Attribution - NonCommercial - NoDerivs (CC BY-NC-ND 3.0) License http://creativecommons.org/licenses/by-nc-nd/3.0/ 